\title{
Practicing sustainability as a backpacker: The role of nationality
}

\author{
Benjamin Lucca laquinto ${ }^{1,2}$ (D) | Stephen Pratt $^{3}$ (D)
}

\author{
${ }^{1}$ Department of Geography, The University of \\ Hong Kong, Hong Kong, China \\ ${ }^{2}$ School of Geography, The University of \\ Melbourne, Carlton, Australia \\ ${ }^{3}$ School of Tourism and Hospitality \\ Management, Faculty of Business and \\ Economics, The University of the South \\ Pacific, Laucala Campus, Suva, Fiji

\section{Correspondence} \\ Benjamin Lucca laquinto, Assistant Professor, \\ Department of Geography, University of Hong \\ Kong, 10/F The Jockey Club Tower, Centennial \\ Campus, Pokfulam Road, Pokfulam, Hong \\ Kong, China. \\ Email: iaquinto@hku.hk
}

\begin{abstract}
The influence of tourist nationality is a consistent topic of interest among tourism researchers. A social practice approach using interviews and participant observation was applied to understand if backpackers of different nationalities (German, British, French, and American) performed different sustainability practices. Backpacking is a homogenising force because of the shared values of frugality combined with the hostel context. Overall, national differences were minor, but there were some differences notably between German and British backpackers. Practicing sustainability required a combination of backpacker values, infrastructures, and corporeal abilities to converge at specific points in time and space.
\end{abstract}

\section{KEYWORDS}

backpacking, social practice theory, sustainable tourism, theories of social practice, tourist nationalities, working holiday makers

\section{1 | INTRODUCTION}

Over the past 10 or so years, backpackers have received substantial attention from sustainable tourism researchers (Canavan, 2018; laquinto, 2015; Nok, Suntikul, Agyeiwaah, \& Tolkach, 2017; Ooi \& Laing, 2010; Pearce, 2008). While backpackers have been known to perform practices of sustainability, at least inadvertently (laquinto, 2015), it is unknown if such practices vary among backpackers from different countries. How nationality shapes the tourism experience has long been a topic of interest among tourism researchers (Oppermann, 1994). Understanding national differences can help differentiate various markets within tourist subgroups, such as backpackers, and it can help clarify the relationship between home and the holiday. This study contributes insights in these two areas by examining the practices of sustainability among backpackers of four nationalities: German, British, French, and American.

Previous studies examining national differences among backpackers have presented mixed findings. Some scholars have argued backpackers are quite heterogeneous (Maoz, 2007; Sørensen, 2003), suggesting differences may exist in the performance of sustainability practices. But others take the opposite view (Hillman, 2009; Pearce, 2005), implying uniformity in the performance of sustainability. Hillman (2009, p. 167) argued that "there is no individualism as the backpackers are a homogenous group. They all act and do similar things." Whereas backpackers are certainly becoming more heterogeneous with the growing numbers of Asian backpackers joining the community, they are still commonly middle class and university educated (Nok et al., 2017).

But the focus in Hillman's work on how backpackers act and what they do highlights the utility of a practice approach for backpacker research. After all, practices can be considered singular performances carried out by individuals. In the words of Lamers, van der Duim, and Spaargaren (2017, p. 56), practices are "routinised 'doings and sayings' performed by knowledgeable and capable human actors." So people's actions, habits, and routines are all considered practices (Reckwitz, 2002). Practices emerge when the three elements of which they are comprised-meanings, competencies, and materials-come together and remain linked (Shove, Pantzar, \& Watson, 2012).

Practice-based approaches are gaining increasing attention in tourism studies (Lamers et al., 2017; Ren, James, \& Halkier, 2019), but whether or not there are variations in practices between nationalities remains unknown. As much practice-based research has been carried out among resident households, further research is needed in tourism contexts. Backpackers from the United Kingdom, Germany, France, and the United States were involved here. The purpose is to 
understand if nationality is a factor in the performance of sustainability among backpackers. Such an insight would contribute to debates regarding the heterogeneity (or otherwise) of backpackers (Maoz, 2007; Pearce, 2005) and determine which backpackers were doing the work of sustainability.

\section{I PRACTICE THEORIES IN TOURISM AND SUSTAINABILITY RESEARCH}

Various theories of social practice have been applied across the social sciences over the past several decades. The study of practices is a diverse field, so there is "no unified practice approach," but the idea that society can be reduced not to individuals but to the practices they perform is a foundational claim of practice theory (Schatzki, 2001, p. 11). Phenomena such as "knowledge, meaning, human activity, science, power, language, social institutions, and historical transformation are all part of or take place within the field of practices" (Schatzki, 2001, 11, original emphasis). There is no mind/body dualism in practice theory because thinking, feeling, and doing are all practices and required for the performance of mental and emotional labour, which has bodily underpinnings (Hochschild, 1983). One of the more highly cited definitions of practice was developed by Reckwitz (2002, 249) who argued that practice was

a routinized type of behaviour which consists of several elements, interconnected to one other: forms of bodily activities, forms of mental activities, "things" and their use, a background knowledge in the form of understanding, know-how, states of emotion and motivational knowledge.

The description of practice as a "type of behaviour" is contested by other practice theorists such as Shove (2010), who argued theories of behaviour and those of practice are incommensurable. Indeed, practice theories embrace a "flat ontology," which is not shared by behavioural theories. A flat ontology means there is only one level of the social-that of practices-so categories such as structure and agency, macro and micro, lack explanatory power (Ren et al., 2019; Spaargaren, Lamers, \& Weenink, 2016). Reality may still be socially constructed (Berger \& Luckmann, 1985), but the process of social construction takes place at the level of practices and nowhere else. Shove et al. (2012) also further clarified practice by arguing that in order for a practice to be performed, there needs to be connections between shared understandings (meanings), bodily skills and abilities (competencies), and infrastructures and objects (materials). Paying attention to the elements of practice helps to understand whether or not practices are performed, and when, where, and why practices occur.

From a practice perspective, tourism could be considered a bundle of interlinked practices composed of "sets of social practices and material arrangements that hang together and are interconnected in more or less strong and enduring ways" (Lamers et al., 2017, p. 57). Backpacking is composed of practices such as socialising, travelling to "off the beaten track" destinations, and budgeting, and it depends on material arrangements such as hostel networks and transportation infrastructure (Cohen, 1973; O'Reilly, 2006; Sørensen, 2003). Theories of social practice can enable understandings of tourist-environment relations, tourist rituals, and how tourism changes over time (Edensor, 2007; Lamers et al., 2017; Rantala, 2019). But practice theories are relatively new to tourism research. While Lamers et al. (2017) argue practice theories have much to offer the study of tourism; more work is needed to fully assess their contribution.

In contrast to some theories of tourism that position it as extraordinary and separate from everyday life, practice theories highlight mundane tourist activities, routines, and habits (de Souza Bispo, 2016; Edensor, 2007). As Edensor (2007, p. 200) argued, tourism involves "unreflexive, habitual and practical enactions which reflect common sense understandings of how to be a tourist." When practice theory was applied to the fields of consumption and sustainability research in the 2000s, the concept of mundane practices and/or everyday practices provided an important theoretical contribution. The concept of everyday practices emerged from the work of de Certeau (1984), who saw practices as a site of resistance and transformation as "everyday life invents itself by poaching in countless ways on the property of others" (de Certeau, 1984, p. xi, original emphasis). But the emancipatory potential of practices is always limited by their ability to reproduce the social order via repetition (Reckwitz, 2002).

In the concept of everyday practices, sustainability is situated as a practice occurring among the routines, habits, and daily activities of people who are going about their lives. It suggests that sustainability-related practices can be performed either with or without conscious awareness as they are a part of the activities and patterns of daily life (Shove, 2010). In research examining how to reduce the resource intensiveness of everyday life, practices enabling resource reduction are usually considered "sustainable" (Shove et al., 2012). While we recognise that sustainability has a diverse range of interpretations, in this study, to practice sustainability is to perform mundane practices that reduce resource consumption and waste such as line drying, taking short showers and recycling. Focusing on practices can reduce sustainability to the individual level, potentially enabling government and corporate elites to avoid responsibility (Shove, 2010). But bringing sustainability down to the individual level can also make it intelligible to people's everyday lives, so there are both strengths and weaknesses to this approach.

Given there is significant variety in how different countries have responded (or not) to the challenges of sustainability, it might be assumed that people of different nationalities would perform different sustainability practices. But a practice perspective suggests otherwise. Backpackers from various countries utilise the same hostels and transport networks, making the material element of their practices relatively uniform. There are also likely to be, as Edensor (2007) suggested, shared understandings of how to be a backpacker across backpackers of different nationalities. We delve into this issue by applying practice-based theoretical literature to a range of conscious, inadvertent, and routine backpacker practices that are performed in the hostel context-an important site for the maintenance and reproduction of backpacker identity. 


\section{3 | BACKPACKER PRACTICES}

Practice theorists make a distinction between practices as performances and practices as entities (Lamers et al., 2017; Shove et al., 2012). To use backpacking as an example, the practices of individual backpackers are the performances, whereas the travel practice of backpacking is the entity. The distinction between practices as entities or performances provides a way to understand how practices can spread across the world and persist over time. Although backpackers have captured the attention of tourism researchers since at least the 1970s, practice-based approaches are exceedingly rare (but see laquinto, 2015). Much more research is needed to understand backpacking from a practice perspective. As the influence of nationality can more easily be determined by examining practices as performances, it is these types of practices that are the focus of this study.

The global prevalence of backpackers means they can have a profound impact on the economies, societies, and environments of destinations around the world and they have an important role to play in the goal of sustainable tourism (Canavan, 2018; Dayour, Adongo, \& Taale, 2016; laquinto, 2015; Nok et al., 2017; Richards \& Wilson, 2004). Backpacking is part of the "experience economy" in which the product for sale is the experience itself (Pine \& Gilmore, 1998). Backpacking is a rite of passage, a transformative experience, a time for risk-taking, and a way for people to find their authentic selves (Canavan, 2018; Fuchs, 2013; O'Reilly, 2006; Tomazos, 2016). Thus, the experiences people have as backpackers can be highly significant and have the potential to shape their ongoing engagement with sustainability issues. Nevertheless, achieving sustainability remains an ongoing challenge for the backpacking industry.

From a practice perspective, nationality in the backpacking context would be discernible via practices such as speaking, dressing, or other forms of bodily comportment. Practices also connect backpackers with sustainability issues and resource consumption-via practices such as shopping, eating, showering, and recycling. Much research has investigated the "pertinence of nationality as a differentiating variable in tourism studies" (Oppermann, 1994, p. 165) highlighting, for example, how nationality is related to tourist distribution or environmental attitudes (McKercher, Pang, \& Prideaux, 2011; Oppermann, 1994). But combining practice theory with nationality in sustainable tourism research is a different and underutilised approach.

In the backpacker literature, Paris, Musa, and Thirumoorthi (2015) revealed some divergent cultural values among Asian and Australasian backpackers. Israeli backpackers are more likely to travel in groups than Western backpackers (Maoz, 2007) and are generally less willing to interact with people of different cultures compared to Danish backpackers (Enoch \& Grossman, 2010). Nationality has also been known to influence the spending practices of backpackers (Dayour et al., 2016), with implications for consumption practices. While the literature reveals some national differences exist between backpackers, little is known of the relationship between backpacker nationality and sustainability. Notwithstanding the increasing use of practice theory in tourism research, it is still usually applied among resident households. Practice theorists have also not adequately addressed the role of nationality in shaping sustainability practices. This research will contribute to filling this gap in the literature.

\section{4 | STUDY METHODS}

This study takes an exclusively qualitative approach, using interviews and participant observation to detect the sustainable practices of backpackers. While acknowledging the debates over the best method for detecting practices (Hitchings, 2012), these two methods were chosen because they were best suited to the backpacking context. As Sørensen $(2003,850)$ argued, "the un-territorialization of the backpacker community means that, instead of prolonged interaction with the few, fieldwork has had to be structured around impromptu interaction with the many." Most fieldwork took place in the common areas of various backpacker hostels, as this enabled large numbers of backpackers to be encountered. The chosen methods were derived from a broader research project completed in 2015 that was based in Australia and investigated the role of mobility in shaping the sustainability practices of backpackers. During this time, the primary author lived as a backpacker across Australia utilising hostel accommodation and backpacker transport infrastructure while "blending in" as a backpacker.

Interviews were the primary method for three main reasons. First, interviews enabled nationality to be easily recorded while participant observation complicated the recording of nationalities. Second, unlike observation, interviews can reveal the meanings or shared understandings, which backpackers ascribe to their practices and which comprise one of the three practice elements. Finally, and contrary to concerns interviews will "interfere" with the social world under investigation (Lamers et al., 2017), talking to other backpackers is an essential part of the backpacker social world (Reichenberger, 2017). Interviews were thus conversational rather than question/answer. Participant observation was used in a supplementary fashion to enrich understandings of the backpacker experience and the practices it entails. In the field, the primary researcher was open about his status as a backpacker/researcher, discussing the research project with other backpackers when the opportunity arose.

\section{1 | "Zooming in" on backpacker practices}

Nicolini (2009) articulates two perspectives from which to detect and understand practices-a "zoomed in" perspective and a "zoomed out" perspective. In this paper, we zoom in on backpacker practices to understand the context in which practices of resource reduction are enacted. Zooming in involves a close engagement with the practices under investigation, the contexts in which they are performed, and reveals how practices are enacted in situ (Spaargaren et al., 2016). It is a perspective that can be acquired by combining interviews and participant observation (Nicolini, 2009), and it was the preferred methodological perspective for this study because we are interested in practices as performances rather than practices as entities (for 
which the zoomed out perspective is more appropriate; Spaargaren et al., 2016).

Schatzki (2001, p. 3) argued that "understanding specific practices always involves apprehending material configurations." Thus, material configurations including the layout of each hostel would have an influence on the types of sustainability practices performed. Participant observation was then useful for understanding the role of hostel layout, objects, and materials in the performance of sustainability practices. Spaargaren et al. (2016) argues that detecting practices effectively requires recognition of the context in which practices are performed. In this study, we engage substantially with one contextual factor-nationality-but we also take into account a range of other factors as interviews were useful for gauging the skills, values, and travel histories (as well as nationalities) of the backpackers. Although participant observation was the secondary method, it was still essential for acquiring this range of insights.

Interview data were collected in three contrasting Australian destinations-Melbourne, Alice Springs, and the Fraser Coast. The inclusion of urban, inland, and coastal settings was done purposefully to account for the diversity of the backpacker experience in Australia as much as possible. Backpackers were approached in the common areas of hostels and in public places, the research was briefly explained, and a purposive sample was acquired using a screening question-"are you a backpacker?"-before the commencement of each interview. All backpackers answered "yes" to this question. Asking potential interviewees to self-identify as backpackers has been used in previous backpacker studies (Reichenberger, 2017). Interviews were recorded with the consent of each interviewee.

At the beginning of each interview, all backpackers were asked to describe their current trip in terms of itineraries, routes, mobilities, practices, and motivations. All backpackers were then asked the same six questions: Do you try to meet the local people when backpacking? Do you try to understand local culture when backpacking? Do you think about your impact on the environment? What do you do about it? What do you spend your money on? Do you think about where your money goes, whether it is to local businesses or corporate chains? The six interview questions were fact-oriented, as they were focused on detecting as many practices as possible. It was also unknown at that stage the context in which practices of sustainability would be performed, if at all. Questions were asked in different sequences and were often phrased differently, depending on the flow of each interview. Questions always pertained to each interviewee's current backpacking trip. Throughout each of the interviews, extra questions were asked to follow up on backpacker responses, and via these follow-up questions, an understanding of the meanings backpackers ascribed to their practices was obtained.

Interview questions were developed through a process of trialand-error during a pilot interview stage among backpackers at hostels in Melbourne. Interviews were usually between 5 and 30 min although some would last for over an hour. We investigated practices of sustainability among four nationalities only (the United Kingdom, Germany, France, and the United States), so there were a total of 51 interviews of relevance. While flying to Australia would be one of the most significant environmental impacts of backpacking, this was not part of the analysis. What was of concern here was investigating the influence of nationality in determining the performance of backpacker sustainability practices.

To avoid extensive debate on the topic of what constitutes nationality and mindful that questioning a person's nationality can be a highly insensitive question, we allowed backpackers to self-identify as belonging to a specific nationality by asking them, "where are you from?" This is a frequent question in the backpacking context, so it was less likely to cause offence. In answer to this question, all 51 interviewees who participated in this study named the country that issued the passport they had used to enter Australia. Interviews were not transcribed. Instead, detailed notes were taken and relevant quotes recorded while listening to the audio recordings. The notes were then arranged into different groups based on nationality and coded manually. Observations were recorded in a notebook and on a laptop on a daily basis.

The largest number of interviews conducted was with backpackers from the United Kingdom (24). An additional 18 interviews were conducted with German backpackers, five with French backpackers and four with backpackers from the United States. These four nationalities were chosen because they were the most common participants and as such will have the most to reveal about the role of backpacker nationality in the performance of sustainability practices. Like previous backpacker studies based in Australia (Ooi \& Laing, 2010), backpackers from Germany and the United Kingdom were the most recurring nationality. There was an almost equal balance of genders interviewed with 23 male interviewees and 28 female interviewees.

\section{5 | RESULTS AND DISCUSSION}

Despite having a general awareness of sustainability issues upon questioning, across all interviews, it was apparent that sustainability issues were not important to backpackers, regardless of nationality. The most significant influence on the performance of sustainability practices was the backpacking context rather than nationality. As we explain below, the backpacker values of frugality and hardship, the hostel infrastructure, and the bodily abilities of backpackers combined to enable the performance of practices that reduced resource consumption. Nationality was not a significant differentiating variable in the performance of sustainability practices among backpackers; however, there some national differences observable in the water- and energy-saving practices of German and British backpackers. Approaches for embedding sustainability into backpacking thus do not have to be fit for purpose or tailored to specific backpacking subgroups.

Backpackers would sometimes respond to questions in a hesitant manner, indicating how sustainability is not a typical discussion topic in the backpacking context. Upon questioning a British backpacker about his sustainable practices, he responded,

Apart from recycling ... kind of putting me on the spot, I can't really think of any, I'm sure there's other ways, not 
really consciously, l'd probably be more ... if the situation arose l'd probably avoid the negative but not go out of my way to do the positive.

As was common among interviewees, this backpacker located his actions within a sustainability discourse only after performing them, and then only in the context of the interview. But such responses were still revealing for what they communicated about backpacker understandings of sustainability-related practices and their performance in tourist settings. This backpacker recognised that his sustainability-related practices might not be performed consciously, highlighting their mundane qualities.

However, just because sustainability is not present in attitudes does not mean it will be absent from practices. In a reversal of the typical "attitude-behaviour" gap (Juvan \& Dolnicar, 2014), backpackers performed sustainability practices without holding prosustainability attitudes. Backpackers are thus inadvertent practitioners of sustainability, "carriers of practice" rather than "autonomous agents of choice and change" (Shove, 2010, p. 1279). As practices have a history that precedes many individual practitioners, practice theorists argue that practices can "recruit" practitioners who go on to become "carriers" (Lamers et al., 2017). Backpacking and the associated hostel network have a long history in Australia, and thus, backpacking entails certain established ways of doing things that are communicated via advertising, social media, guidebooks, and word of mouth.

\section{1 | Practices of resource reduction}

Backpackers across all nationalities mentioned performing the sustainable practices of recycling, reducing water and energy use, and the proper disposal of rubbish. Table 1 shows how many interviewees of each nationality performed these four practices. Reducing water use was performed via a number of different practices: taking shorter showers, taking fewer showers, washing clothes by hand, and turning off the tap while brushing teeth. Reducing energy use was performed via a similarly diverse array of practices: overland travel, turning off lights when leaving a room, line drying clothes, and air drying hair Because hot showers are a societal norm, taking shorter and/or fewer showers are practices enabling reductions in both water and energy. Backpackers commonly gave the impression their sustainable practices were habitual-they performed them not explicitly out of environmental concerns but because they routinely performed them at home.

I try not to spill water, try not to throw rubbish, put it in recycle. Just like at home. (French backpacker)

TABLE 1 Sustainability practices performed by interviewees

\begin{tabular}{lccccc} 
Nationality & Interviewees & Recycling & $\begin{array}{c}\text { Saving } \\
\text { water }\end{array}$ & $\begin{array}{l}\text { Saving } \\
\text { energy }\end{array}$ & $\begin{array}{l}\text { Not } \\
\text { littering }\end{array}$ \\
\hline British & 24 & 6 & 4 & 6 & 5 \\
\hline German & 18 & 3 & 8 & 7 & 2 \\
\hline French & 5 & 3 & 2 & 2 & 1 \\
\hline American & 4 & 1 & 2 & 1 & 2 \\
\hline
\end{tabular}

They make it very easy for you at the hostel. They have a bin for this and a bin for that. It's not an issue you just do it. (German backpacker)

The practices of saving water, saving energy, recycling, and disposing of rubbish are types of everyday sustainability practices examined by researchers grappling with the issue of how to integrate sustainability into daily life (Shove, 2010; Shove et al., 2012). Holidays have been known to disrupt the routines of home because of the meanings people ascribe to tourism (Juvan \& Dolnicar, 2014). But for backpackers, hostels provided a stage for the performance of routine environmental practices. The hostel thus provided one of the key elements of practices-the materials. The hostel provides essential items and material structures-kitchens, bathrooms, showers, lounge areas, recycling bins, rubbish bins, "free food" shelves, and clothes lines.

But practices would not be performed if only the material element of practice was present. The meanings people ascribe to practices also play an essential role in their performance (Shove et al., 2012). As backpacking is a form of tourism in which experiencing hardship and practicing frugality are highly valued (Sørensen, 2003), daily showering would be considered an extravagance, and cleaning clothes in a washing machine would be considered too costly. A British backpacker mentioned the issue of showers explicitly, saying "a hot shower at a hostel is quite a luxury sometimes." The social values ascribed to backpacking thus encourage practices of water and energy conservation. Water-saving practices, for example, were enabled by the connections between the backpacker social values of frugality, the material presence of showers, and the bodily abilities necessary to enable brief showering and other water-saving practices. Connecting each of these elements was necessary for the practice of saving water to be performed, and it was the backpackers whose physical presence within hostels enabled those connections to be made.

Nevertheless, national differences were observable. German backpackers were the most likely to perform water- and energy-saving practices and British backpackers the least likely (given the number of interviewees). German backpackers explained how they performed an array of practices to reduce water and energy. For example, they explained, "you don't need a shower every day," "I shut the tap when I wash my hair," "I use the clothesline," and "I don't blow dry my hair." Despite such options readily available to all backpackers, Table 1 shows British backpackers were proportionally the least likely to save water and energy with only four mentioning they performed watersaving practices and six mentioning they saved energy (out of a total of 24 British interviewees). Two of the five French interviewees mentioned water- and energy-saving practices and two of the four American interviewees also mentioned saving water, whereas one mentioned saving energy.

The practice element of meaning explains the national differences between UK and German backpackers in terms of water consumption. Water intensive practices are increasing in the UK, particularly among young people (Pullinger, Browne, Anderson, \& Medd, 2013). The showering practices of British youth are more intensive because of high standards of cleanliness combined with their socially and 
physically active lives. It is common for young people in the UK to shower after the gym, before going out to socialise, and before work or school (Pullinger et al., 2013). In Germany, Schleich and Hillenbrand (2009) report that between 1991 and 2004 per capita water consumption declined, particularly in areas where the price of water was relatively high and household income was relatively low.

During fieldwork the first author had already developed the competencies required to take short showers as water shortages and droughts are common in Australia. As one British backpacker explained, "in Australia they don't give a flying fuck about recycling but they're really strict with their water." However, the general state of uncleanliness of hostel shower stalls and the large numbers of backpackers sharing the few showers provided meant that the first author also took both fewer and shorter showers during fieldwork. Thus, the practice of showering in the backpacking context involved combining skills learned at home with new arrangements of materials and meanings specific to backpacking, which resulted in more reductions in water and energy consumption compared to home.

The practice element of meaning was also significant in the performance of energy-saving practices such as overland travel, line drying clothes, and air drying hair. All were informed by the backpacker values of frugality and/or hardship. Such values were communicated in interviews in comments such as "what we're really doing here (in Australia) is just surviving" (American backpacker) and "when I lived in Melbourne (as a backpacker) it was an easy life, no showers, no power, but I was always happy" (German backpacker). Backpackers of all nationalities performed a limited number of sustainability practices. Although there were national differences in terms of how many backpackers of each nationality performed them, backpackers of all nationalities performed only four identifiable sustainability practices (see Table 1).

\section{2 | Combining and changing practice elements}

Studies have found that water consumption was also influenced by age. Younger people consumed more in the United Kingdom, but in Germany, older people were the bigger consumers (Pullinger et al., 2013; Schleich \& Hillenbrand, 2009). As backpackers are generally younger, the water consumption practices among German and British backpackers match the water consumption practices each performed at home. But it does not explain why young people in the United Kingdom consume more water than young people in Germany, even though German youth could be assumed to be just as physically and socially active. The explanation is likely to be due to the practice element of meaning. As one British backpacker explained, "in the UK it's very much drummed into us, it's all about recycling and not about water." As for German backpackers,

In Germany I'm quite aware (of the environment) I only have lights on in the room I'm sitting in. I try not to take a shower for like half an hour. (German backpacker).

I take quite short showers here. At home it's different I'm in my own bathroom and I like to be in my own bathroom. Here it's like everyone wants it so I just take quick showers. (German backpacker)

According to the British backpacker quoted above, she consistently encounters messages about the importance of saving water when at home, which she then carries into the backpacking context. Similarly, the first German backpacker quoted above carried her home-based environmental awareness into the backpacking context. For the second German backpacker quoted, the backpacking context transformed the water intensive hygiene practices of home into the sustainable practice of short showering. As for recycling, the material element of this practice often thwarted the ability of Germans to recycle, as one German backpacker explained, "I don't like that you're not recycling here. In Germany we recycle everything." In this case, two of the practice elements-meanings and skills-were linked but disconnected from the material element because of a lack of facilities. Thus, the practice of recycling was performed only in hostels providing such facilities despite backpackers possessing the skills and shared understandings required to perform them.

Some practice elements were more influential than others. Meanings identifying water as a precious resource influenced the British backpacker to perform water-saving practices. This specific practice element was particularly strong, as it persisted even between home and the holiday, affirming Edensor's $(2007,200)$ observation that "tourists carry quotidian habits and responses with them along with their luggage." For the first German backpacker, meaning was also a crucial element for the performance of water-saving practices. In this case, meaning was provided by her environmental awareness-the recognition that water should not be wasted. Meaning was a highly durable element of practice, as it persisted even as the materials changed. The importance of meanings and tacit understandings in the performance of sustainability practices was articulated by an American backpacker who said "(as a backpacker) you're not connected to the idea you're being wasteful we're just living how everyone else is living."

Tourism has been found to disrupt the proenvironmental practices of home (Juvan \& Dolnicar, 2014). But the backpacking context was not sufficiently disruptive because of the durability of the meanings ascribed to such water- and energy-saving practices as taking shorter showers. As for the second German backpacker, the water intensive practices of home were discontinued in the hostel because of a change in materials. The material presence of more shower users influenced the meanings ascribed to showering. At home, showering was about belonging and entitlement-"my own bathroom"-but in the hostel context, the meanings that informed practices of showering changed, removing the sense of entitlement and belonging. When attempting to achieve sustainable tourism, it is important to consider how the frugal values of backpackers can be recruited by other tourist types. But as backpackers performed sustainability practices on holiday, bringing those practices back home requires attention to questions of practice mobility and how new practitioners in home-based contexts can be recruited to the water- and energy-saving practices of backpacking. 


\section{6 | CONCLUSION: FOREGROUNDING} MATERIALS AND MEANINGS IN BACKPACKER SUSTAINABILITY PRACTICES

Using a practice approach with qualitative interviews and participant observation, we explored the role nationality played in shaping the sustainability practices of German, British, French, and American backpackers. The most significant national differences were observable when German and British backpackers performed water-saving practices (see Table 1). Policy makers and hostel managers interested in promoting proenvironmental practices should focus most intently on the meaning and material elements of practice. These proved to be the most significant for the performance of resource reduction practices in the backpacking context. Furthermore, findings from this study can inform future research on the attitude-behaviour gap. Perhaps, there is a practice-based explanation for why people who express proenvironmental attitudes do not perform proenvironmental practices. It could be that the tourism context lacks one or more of the practice elements required for the performance of such practices. This would be worth exploring in future sustainable tourism research.

It has long been recognised that some backpackers maintain their backpacker identity after returning home by keeping in touch with people they met on holiday (Sørensen, 2003). If the meanings that promote frugality in the backpacking context continue to be valued among backpackers after their holidays have finished, those sustainability practices will have a greater chance of being reproduced at home. As Rantala (2019) argued, the rhythms of tourism can travel back home in the form of corporeal practices. Indeed, this study has shown that some water-saving practices of home are enacted in the backpacking context, so it does raise the possibility of backpacker practices enduring outside the specific social context of backpacking.

Reducing water and energy were performed via a number of different practices. This arrangement of practices comprised a water- and energy-saving practice bundle linked via the practices of taking shorter and/or fewer showers. It would be helpful to "zoom out" to understand backpacker sustainability practices both at home and in tourism contexts, and the relationships between them. Doing so would help explore the relationship between home and the holiday in more detail. It would highlight which sustainability practices were the most durable and the most connected with other practices persisting across different consumption contexts. It would also help to more firmly embed sustainability practices in tourism contexts.

One of the reasons why backpackers were able to perform sustainability practices was via the hostel context because it usually provided the infrastructure (i.e., materials) to make them possible. Backpackers had access to communal recycling facilities, clothes lines, bins, and showers. Not all tourism contexts have such facilities. Infrastructure provision should be an important concern for those attempting to promote sustainability practices among tourists, particularly because many sustainability practices were habitual or carried from home. For tourism managers, it might be tempting to attract German backpackers, as they are the most likely to reduce water and energy consumption. Given the high cost of water and power in Australia, this might be particularly appealing. However, this would risk discrimination against backpackers from certain countries.

What should be highlighted instead are the overall similarities among backpackers from around the world. It is remarkable that despite the political and social differences across these countries, backpackers in our study performed a relatively similar array of sustainability practices. As Hillman (2009) suggested, backpacking is a homogenising force. In our study, there were two main reasons for this-the shared values of frugality and hardship combined with the shared hostel context, which led to the performance of a relatively uniform array of sustainability practices across nationalities. Our study shows how tourism can act as a site of collective action for sustainability, suggesting tourism could be enrolled into the degrowth movement (Kallis, 2011). Backpacking potentially enables a type of "sustainability training" in which people learn to live with lower levels of consumption, which will become important as climate change intensifies (cf. Rantala, 2019).

As with any research, there are limitations to be discussed. It would be useful to quantify the extent to which backpackers from different nationalities undertake sustainability practices. Results from a follow-up quantitative study would enable tourism businesses to target specific practices to enhance sustainability and to statistically test the extent to which different practices were clustered. There might also be more significant differences between nationalities if different definitions of sustainability or nationality were applied, or if the study was conducted outside the hostel context. Similar studies in other countries would allow deeper understanding of practices of sustainability in tourism contexts. We leave this research for other scholars to pursue.

\section{ORCID}

Benjamin Lucca laquinto (D) https://orcid.org/0000-0002-6139-4467

Stephen Pratt (D) https://orcid.org/0000-0002-6550-132X

\section{REFERENCES}

Berger, P. L., \& Luckmann, T. (1985). The social construction of reality: A treatise in the sociology of knowledge. Harmondsworth: Penguin.

Canavan, B. (2018). An existentialist exploration of tourism sustainability: Backpackers fleeing and finding themselves. Journal of Sustainable Tourism, 26(4), 551-566. https://doi.org/10.1080/09669582.2017. 1361430

Cohen, E. (1973). Nomads from affluence: Notes on the phenomenon of drifter-tourism. International Journal of Comparative Sociology, 14, 89-103. https://doi.org/10.1177/002071527301400107

Dayour, F., Adongo, C. A., \& Taale, F. (2016). Determinants of backpackers' expenditure. Tourism Management Perspectives, 17, 36-43. https://doi. org/10.1016/j.tmp.2015.11.003

de Certeau, M. (1984). ThePractice of Everyday Life. Berkeley: University of California Press.

de Souza Bispo, M. (2016). Tourism as practice. Annals of Tourism Research, 61, 170-179. https://doi.org/10.1016/j.annals.2016.10.009 
Edensor, T. (2007). Mundane mobilities, performances and spaces of tourism. Social \& Cultural Geograph, 8(2), 199-215. https://doi.org/ 10.1080/14649360701360089

Enoch, Y., \& Grossman, R. (2010). Blogs of Israeli and Danish backpackers to India. Annals of Tourism Research, 37, 520-536. https://doi.org/ 10.1016/j.annals.2009.11.004

Fuchs, G. (2013). Low versus high sensation-seeking tourists: A study of backpackers' experience risk perception: Sensation seeking and perceived risk. International Journal of Tourism Research, 15, 81-92. https://doi.org/10.1002/jtr.878

Hillman, W. (2009). Veblen and the theory of the backpacker leisure class: Status seeking and emulation in the Australian contemporary tourist economy. Tourism Review International, 13, 157-171. https://doi.org/ $10.3727 / 154427210 \times 12684119879521$

Hitchings, R. (2012). People can talk about their practices: People can talk about their practices. Area, 44, 61-67. https://doi.org/10.1111/ j.1475-4762.2011.01060.x

Hochschild, A. R. (1983). The managed heart. Commercialization of human feeling. Berkeley: University of California Press.

laquinto, B. L. (2015). "I recycle, I turn out the lights": Understanding the everyday sustainability practices of backpackers. Journal of Sustainable Tourism, 23, 577-599. https://doi.org/10.1080/09669582.2014. 978788

Juvan, E., \& Dolnicar, S. (2014). The attitude-behaviour gap in sustainable tourism. Annals of Tourism Research, 48, 76-95. https://doi.org/ 10.1016/j.annals.2014.05.012

Kallis, G. (2011). In defence of degrowth. Ecological Economics, 70(5), 873-880. https://doi.org/10.1016/j.ecolecon.2010.12.007

Lamers, M., van der Duim, R., \& Spaargaren, G. (2017). The relevance of practice theories for tourism research. Annals of Tourism Research, 62, 54-63. https://doi.org/10.1016/j.annals.2016.12.002

Maoz, D. (2007). Backpackers' motivations the role of culture and nationality. Annals of Tourism Research, 34, 122-140. https://doi.org/ 10.1016/j.annals.2006.07.008

McKercher, B., Pang, S. F. H., \& Prideaux, B. (2011). Do gender and nationality affect attitudes towards tourism and the environment? International Journal of Tourism Research, 13, 266-300. https://doi. org/10.1002/jtr.816

Nicolini, D. (2009). Zooming in and out: Studying practices by switching theoretical lenses and trailing connections. Organization Studies, 30(12), 1391-1418. https://doi.org/10.1177/0170840609349875

Nok, L. C., Suntikul, W., Agyeiwaah, E., \& Tolkach, D. (2017). Backpackers in Hong Kong-Motivations, preferences and contribution to sustainable tourism. Journal of Travel \& Tourism Marketing, 34(8), 1058-1070. https://doi.org/10.1080/10548408.2016.1276008

O'Reilly, C. C. (2006). From drifter to gap year tourist. Annals of Tourism Research, 33, 998-1017. https://doi.org/10.1016/j.annals.2006. 04.002

Ooi, N., \& Laing, J. H. (2010). Backpacker tourism: Sustainable and purposeful? Investigating the overlap between backpacker tourism and volunteer tourism motivations. Journal of Sustainable Tourism, 18 191-206. https://doi.org/10.1080/09669580903395030

Oppermann, M. (1994). Relevance of nationality in tourism research. Annals of Tourism Research, 21, 165-168. https://doi.org/10.1016/ 0160-7383(94)90018-3

Paris, C. M., Musa, G., \& Thirumoorthi, T. (2015). A comparison between Asian and Australasia backpackers using cultural consensus analysis. Current Issues in Tourism, 18, 175-195. https://doi.org/10.1080/ 13683500.2014.920771
Pearce, P. (2008). Sustainability research and backpacker studies: Intersections and mutual insights. In K. Hannam, \& I. Ateljevic (Eds.), Backpacker Tourism: Concepts and Profiles (pp. 38-53). Clevedon: Channel View.

Pearce, P. L. (2005). Great divides or subtle contours? Contrasting British, North American/Canadian and European backpackers. In B. West (Ed.), Down the road: Exploring backpacker and independent travel (pp. 131-151). Perth: API Network.

Pine, B. J. II, \& Gilmore, J. (1998). Welcome to the experience economy. Harvard Business Review July-August, 76, 97-105.

Pullinger, M., Browne, A., Anderson, B., \& Medd, W. (2013). Patterns of water: The water related practices of households in southern England, and their influence on water consumption and demand management. Lancaster: Lancaster University. Retrieved from https://www. escholar.manchester.ac.uk/uk-ac-man-scw:187780

Rantala, O. (2019). With the rhythms of nature: Reordering everyday life through holiday living. In L. James, C. Ren, \& H. Halkier (Eds.), Theories of Practice in Tourism (pp. 58-76). Oxon: Routledge.

Reckwitz, A. (2002). Toward a theory of social practices a development in culturalist theorizing. European Journal of Social Theory, 5(2), 243-263. https://doi.org/10.1177/13684310222225432

Reichenberger, I. (2017). Why the host community just isn't enough: Processes and impacts of backpacker social interactions. Tourist Studies, 17, 263-282. https://doi.org/10.1177/1468797616665770

Ren, C., James, J., \& Halkier, H. (2019). Practices in and of tourism. In L. James, C. Ren, \& H. Halkier (Eds.), Theories of Practice in Tourism (pp. 1-9). Oxon: Routledge.

Richards, G., \& Wilson, J. (2004). Drifting towards the Global Nomad. In G. Richards, \& J. Wilson (Eds.), The Global Nomad: Backpacker travel in theory and practice (pp. 3-13). Clevedon: Channel View. https://doi.org/ 10.21832/9781873150788-003

Schatzki, T. R. (2001). Introduction practice theory. In K. Knorr Cetina, K. T. R. Schatzki, \& E. von Savigny (Eds.), The practice turn in contemporary theory (pp. 10-23). Hoboken: Taylor and Francis.

Schleich, J., \& Hillenbrand, T. (2009). Determinants of residential water demand in Germany. Ecological Economics, 68, 1756-1769. https:// doi.org/10.1016/j.ecolecon.2008.11.012

Shove, E. (2010). Beyond the ABC: Climate change policy and theories of social change. Environment and Planning A, 42, 1273-1285. https:// doi.org/10.1068/a42282

Shove, E., Pantzar, M., \& Watson, M. (2012). The dynamics of social practice: Everyday life and how it changes. London: Sage. https://doi.org/ 10.4135/9781446250655.n1

Sørensen, A. (2003). Backpacker ethnography. Annals of Tourism Research, 30, 847-867. https://doi.org/10.1016/S0160-7383(03)00063-X

Spaargaren, G., Lamers, M., \& Weenink, D. (2016). Introduction: Using practice theory to research social life. In G. Spaargaren, D. Weenink, \& M. Lamers (Eds.), Practice theory and research: Exploring the dynamics of social life (pp. 3-27). Oxon: Routledge. https://doi.org/10.4324/ 978131565690

Tomazos, K. (2016). Backpacking through an ontology of becoming: A never-ending cycle of journeys. International Journal of Tourism Research, 18, 140-148. https://doi.org/10.1002/jtr.2040

How to cite this article: laquinto BL, Pratt S. Practicing sustainability as a backpacker: The role of nationality. Int J Tourism Res. 2020;22:100-107. https://doi.org/10.1002/jtr.2321 